Terakreditasi

Ditjen Penguatan Riset dan Pengembangan, Kemenristekdikti

Keputusan No: 21/E/KPT/2018, Tanggal 9 Juli 2018
September 2020, 7(3):189-195

DOI: http://dx.doi.org/10.33772/jitro.v7i3.11396

http://ojs.uho.ac.id/index.php/peternakan-tropis

\title{
Usaha Ternak Domba sebagai Jalur Keluar dari Kemiskinan Buruh Tani di Perdesaan
}

\author{
Sondi Kuswaryan*, Cecep Firmansyah, Muhammad Hasan Hadiana \\ Fakultas Peternakan Universitas Padjadjaran \\ Jl. Raya Bandung-Sumedang km. 21, Jatinangor Sumedang 45363 \\ *Email korespondensi: sondi.kuswaryan@unpad.ac.id \\ (Diterima 10-03-2020; disetujui 05-09-2020)
}

\begin{abstract}
ABSTRAK
Penelitian ini bertujuan untuk mengevaluasi kemungkinan usaha ternak domba sebagai aktivitas nafkah untuk pengentasan kemiskinan, serta menentukan jumlah kepemilikan domba yang dapat membawa rumah tangga buruh tani keluar dari kemiskinan. Survey telah dilakukan di Desa Walangsari Kecamatan Kalapanunggal Kabupaten Sukabumi, melibatkan rumah tangga buruh tani miskin sebanyak 65 orang dan 22 orang tidak miskin. Faktor yang berpengaruh terhadap kemiskinan dianalisis menggunakan model regresi logistik biner, sedangkan jumlah kepemilikan domba yang harus dipelihara untuk keluar dari kemiskinan ditentukan dengan model regresi sederhana. Hasil penelitian menunjukkan bahwa usia kepala keluarga, dan pengalaman beternak tidak mempengaruhi kemiskinan, sedangkan jumlah kepemilikan domba, jumlah anggota rumah tangga, keterlibatan dalam kelembagaan, serta sumber pendapatan dari non pertanian mempengaruhi status kemiskinan rumah tangga buruh tani. Pada rata-rata jumlah anggota rumah tangga sebanyak 4,45 orang,untuk keluar dari kemiskinan buruh tani harus memelihara minimal sebanyak 36,63 ekor domba per rumah tangga. Hasil penelitian ini menegaskan bahwa usaha ternak domba dapat digunakan sebagai sarana untuk pengentasan kemiskinan buruh tani, program pengentasan kemiskinan akan efektif bila melibatkan kelembagaan lokal.
\end{abstract}

Kata Kunci: buruh tani, jumlah kepemilikan domba, kemiskinan

\begin{abstract}
This study aims to determine the possibility of sheep farming as a livelihood activity for poverty alleviation and to determine the amount of sheep ownership that can bring farm laborers households out of poverty. Survey research has been carried out in Walangsari Village, Kalapanunggal District, Sukabumi Regency, involving 65 poor farmer households and 22 non-poor households. Factors affecting poverty were analyzed using a binary logistic regression model, while the number of sheep ownership needed to escape poverty was determined by a simple regression model. The results showed that the age of the head of the family, and experience of sheep farmers did not affect poverty, while the number of sheep ownership, number of household members, involvement in institutions, and sources of income from non-agriculture affected the poverty status of farm laborers' households. In the average number of household members as many as 4.45 people, to get out of poverty must maintain a minimum of 36.63 sheep per household. This research explains that sheep farming can be used as a means to reduce the poverty of farm laborers, and poverty alleviation programs will be effective if they involve local institutions.
\end{abstract}

Keywords: farm labor, number of sheep ownership, poverty

\section{PENDAHULUAN}

Berdasarkan Badan Pusat Statistik (BPS) pada Maret 2019, penduduk miskin di Jawa Barat mencapai 3.399,16 ribu orang, sebanyak 9,79\% merupakan penduduk perdesaan dan 6,03\% merupakan penduduk miskin perkotaan. Fenomena yang sama terjadi di Kabupaten Sukabumi dimana
8,04\% penduduk berstatus miskin (BPS, 2017), mereka sebagian besar tinggal di perdesaan. Desa Walangsari Kecamatan Kalapanunggal Kabupaten Sukabumi merupakan salah satu desa dengan tingkat kemiskinan yang cukup tinggi. Penyerapan lapangan kerja pertanian relatif kecil, karena sebagian besar lahan merupakan lahan darat, 
dengan sumber air yang terbatas. Oleh karena itu sebagian besar penduduknya menjalankan multi aktivitas nafkah sebagai sumber pendapatan; antara lain buruh tani, buruh bangunan, pedagang, pelaku jasa transportasi dan juga buruh migran di perkotaan.

Sumber pendapatan lain yang diandalkan masyarakat, khususnya buruh tani adalah memelihara domba. Pilihan aktivitas nafkah beternak domba merupakan pilihan rasional, karena domba berperan penting dalam mempertahankan dan meningkatkan derajat penghidupan, ternak mampu mengkonversikan sebagian besar vegetasi alam (limbah pertanian, rumput di padang penggembalaan, atau dedaunan dari pohon) menjadi produk yang bernilai ekonomi (Randolph et al., 2007; Biradar et al., 2013), namun dengan biaya input murah (Johnson et al.,1986). Di berbagai negara berkembang, ternak mempunyai peran vital dalam perekonomian masyarakat, ternak merupakan sumber pangan protein hewani, sumber pendapatan, sumber lapangan kerja serta sumber devisa (Maltsoglou \& Rapsomanikis, 2005; Randolph et al., 2007; Ciamarra et al., 2011).

Pada masyarakat berpendapatan rendah, ternak merupakan sarana penyimpan kekayaan, sumber tenaga kerja, sumber pupuk organik tanaman dan sarana transportasi (Ciamarra, 2005; Swanepoel et al., 2010; Bettencourt et al., 2015). Ternak merupakan komoditas bernilai tinggi (daging, telur, susu dan lain lain), dan berkontribusi besar dalam pertumbuhan ekonomi, melalui keterkaitan ke depan (produk ternak dan pasar) dan ke belakang (permintaan input dan layanan ternak), penanggulangan urbanisasi, serta berperan penting dalam pelestarian lingkungan, meskipun ada beberapa efek negatif dari eksistensi ternak (Swanepoel et al., 2010).

Peternakan dalam sistem penghidupan masyarakat miskin perdesaan mengambil peranan penting, karena ternak bersifat multifungsi, yaitu sebagai sumber pangan, fungsi sosial, penyangga resiko dari kegagalan panen, sumber pupuk dan tenaga kerja pertanian, sumber pendapatan dan akumulasi harta (Randolph et al., 2007). Bagi rumah tangga miskin, ternak merupakan tabungan yang mudah diuangkan, akumulasi aset, untuk menjaga keamanan finansial, menanggulangi pengeluaran yang tidak terencana, serta sebagai perangkat asuransi dan akun bank (Swanepoel et al., 2010; Bettencourt et al., 2015). Ternak berperan sebagai buffer terhadap risiko investasi dan aset untuk pengembangan usaha (Johnson et al., 1986; Sarwono, 1992; Kumar et al., 2006; Randolph et al., 2007)).

Di Jawa Barat jenis ternak yang paling disukai untuk dipelihara adalah domba. Kajian Kuswaryan et al. (2016) dan Kuswaryan \& Firmansyah. (2017), menginformasikan bahwa usaha ernak domba berkontribusi besar terhadap pendapatan total rumah tangga. Fleksibilitas domba sebagai sebagai aset mudah cair memungkinkan ternak dijual sesuai dengan kejadian membutuhkan uang kontan (Udo \& Budisatria, 2011; Ugwu, 2014). Pada sistem pertanian tradisional, kepemilikan ternak ruminansia kecil merupakan potensi yang sangat rasional sebagai sumber penerimaan ekonomi dan simbol status (Ugwu, 2007). Ternak merupakan sumber pendapatan penting, khususnya dalam mengatasi kelaparan pada musim tidak produktif/kering dan secara umum merupakan sumberdaya kedua terpenting dalam penghidupan masyarakat setelah lahan (Tembo et al., 2014).

Buruh tani miskin di Desa Walangsari Kecamatan Kalapanunggal Kabupaten Sukabumi relatif sulit untuk keluar dari kemiskinan karena terbatasnya aset produktif yang dapat diakses, namun demikian hampir setiap rumah tangga memelihara domba. Di Desa Walangsari domba berperan penting dalam penghidupan rumah tangga buruh tani, namun dari berbagai sisi (teknis, sosial dan ekonomi) pemanfaatannya belum optimal, baik sebagai tabungan (store) maupun aset produktif. Usaha ternak domba dapat dikembangkan sebagai aktivitas nafkah untuk pengentasan kemiskinan, khususnya untuk rumah tangga buruh tani. Sampai saat ini penelitian mengenai domba sebagai komoditas usaha untuk pengentasan kemiskinan belum banyak diungkap. Penelitian ini bertujuan untuk menginventarisasi variabel yang berpengaruh terhadap kemiskinan dan memberikan informasi mengenai adanya kesempatan domba digunakan sebagai komoditas usaha untuk mengentaskan kemiskinan buruh tani di perdesaan.

\section{METODE}

Penelitian ini menggunakan metode survei, dilakukan terhadap buruh tani yang memelihara domba di Desa Walangsari Kecamatan Kalapanunggal Kabupaten Sukabumi. Jumlah responden sebanyak 87 orang, terdiri dari 65 orang berstatus miskin dan 22 orang berstatus tidak miskin. 


\section{Model Analisis}

Model umum untuk estimasi regresi logistik biner dapat ditulis sebagai berikut (Asra et al., 2017)

$$
l\left(\frac{p_{i}}{1-p_{i}}\right)=\beta_{0}+\beta_{1} x_{2}+\beta_{2} x_{2}+\cdots+\beta_{5} x_{5}
$$

Dimana :

$\mathrm{X}_{1}$ : Pengalaman beternak domba (tahun)

$\mathrm{X}_{2}$ : Mempunyai usaha non pertanian $=1$ dan tidak mempunyai usaha non pertanian $=0$

$\mathrm{X}_{3}$ : Anggota kelompok peternak $=1$ dan bukan anggota kelompok peternak $=0$

$\mathrm{X}_{4}:$ Jumlah kepemilikan domba (ekor)

$\mathrm{X}_{5}$ : Usia kepala rumah tangga (tahun)

$\mathrm{X}_{6} \quad$ : Jumlah anggota rumah tangga (orang)

$\mathrm{Y}: 1$ untuk rumah tangga buruh tani peternak domba yang tidak miskin

Y : 0 untuk rumah tangga buruh tani peternak domba yang miskin

Status rumah tangga buruh tani peternak domba miskin dan tidak miskin menggunakan batasan BPS Jawa Barat. Pada bulan Maret 2019 batas miskin menurut BPS Jawa Barat adalah sebesar Rp 376.680/kapita/bulan untuk pengeluaran pangan dan non pangan di perdesaan.

Keberlakuan model logistik biner terlebih dahulu diuji dengan Uji Kecocokan Model (goodness of fit test) menggunakan Tabel Hosmer and Lemeshow Test, bila nilai $p$-value $>0,05$ artinya model dapat digunakan untuk menjelaskan hubungan antara status kemiskinan dengan variabel bebasnya. Untuk mengetahui model mampu mengklasifikasikan objek secara benar digunakan besaran Hit Ratio (percentage correct dan overall percentage pada classification table. Uji keseluruhan menggunakan Omnibus Tests of Model Coefficients Table), bila p-value <5\%, artinya minimal ada satu variabel bebas secara statistik berpengaruh signifikan terhadap peluang status kemiskinan rumah tangga buruh tani ternak domba. Uji Parsial menggunakan hasil statistik uji Wald, bila nilai statistik Wald lebih besar dari nilai kritis $X^{2}$ pada derajat bebas 1 pada tingkat signifikansi sebesar 5\%, atau nila $p$-value $<5 \%$ variabel berpengaruh nyata terhadap status kemiskinan buruh tani ternak domba.

\section{Penentuan Jumlah Kepemilikan Domba untuk Pengentasan Kemiskinan}

Penentuan jumlah kepemilikan domba yang optimal pada tingkat batas kemiskinan menggunakan proyeksi dari fungsi hubungan antara jumlah pemilikan (X) dengan jumlah pendapatan rumah tangga (Y), menggunakan metode kuadrat terkecil (Chiang, 1974).

$$
\mathrm{Y}=\mathrm{a}+\mathrm{bX}+\varepsilon
$$

Bila $\mathrm{Y}$ adalah pendapatan pada batas kemiskinan rumah tangga (Rp/rumah tangga/tahun), maka jumlah kepemilikan domba minimal (X) dapat ditentukan.

\section{HASIL DAN PEMBAHASAN}

\section{Keadaan Umum Wilayah Penelitian}

Desa Walangsari termasuk wilayah Kecamatan Kalapanunggal Kabupaten Sukabumi (Gambar 1), berada di sebelah barat Gunung Salak, rata-rata ketinggian wilayah pada kisaran 500-700 dpl, dengan topografi pada kemiringan $15^{\circ}-25^{\circ}$. Dari total luas wilayah desa 702 hektar, 100 hektar merupakan lahan sawah, sebagian besar merupakan sawah tadah hujan, 302 hektar merupakan lahan pertanian lahan kering (kebun campuran dan ladang) dan 300 hektar lainnya dimanfaatkan untuk berbagai kepentingan.

Jumlah kepala keluarga (KK) sebanyak $1.736 \mathrm{KK}$, sebagian besar (50,17 persen) sumber penghasilan utamanya berasal dari sektor pertanian. Di samping sumber pendapatan dari off farm dan non farm, sumbangannya berasal dari sub sektor peternakan, khususnya ternak domba, dengan dukungan populasi sebanyak 3.545 ekor. Pola pemanfaatan lahan didominasi oleh lahan sawah tadah hujan, menggambarkan besarnya potensi sumberdaya rumput atau limbah pertanian yang dapat dimanfaatkan untuk mendukung berkembangnya peternakan.

\section{Profil Buruh Tani Ternak Domba}

Penduduk perdesaan dengan kepemilikan lahan yang terbatas atau tidak memiliki lahan pada umumnya bekerja sebagai buruh tani (off farm) sebagai sumber pendapatan, namun karena lapangan kerja pertanian tanaman pangan sangat terbatas, banyak diantara mereka bekerja sebagai buruh di luar sektor pertanian (non farm) di perdesaan atau perkotaan. Disamping tingkat upah buruh yang rendah serta jumlah hari kerja untuk berburuh tani selama setahun terbatas, pada umumnya tidak mampu menghasilkan pendapatan yang dapat memenuhi kebutuhan rumah tangganya. Memenuhi kekurangan pendapatan dan untuk mengupayakan penghidupan yang lebih baik, sebagian besar buruh perdesaan membangun aktivitas nafkah tambahan dengan beternak domba. Usaha ternak domba sebagai pilihan nafkah menunjukkan peran yang makin penting dalam penghidupan buruh tani, kondisi ini dapat dilihat pada profil buruh tani (Tabel 1). 




Gambar 1. Posisi Desa Walangsari, Kecamatan Kalapanunggal Kabupaten Sukabumi

Peran usaha ternak domba pada rumah tangga buruh tani lebih dominan sebagai sumber pendapatan dibandingkan usaha lainnya. Usaha ternak domba merupakan aktivitas nafkah perdesaan yang membutuhkan aset relatif kecil, sedangkan usaha non farm membutuhkan aset relatif besar yang tidak dapat dipenuhi oleh sebagian besar rumah tangga buruh tani miskin. Buruh tani tidak miskin mempunyai kemampuan penyediaan aset yang lebih baik untuk membangun aktivitas nafkah di luar sektor pertanian (non farm), seperti pedagang, buruh transportasi atau pekerja migran perkotaan. Oleh karena itu sumbangan sektor non farm terhadap total pendapatan rumah tangga relatif lebih besar daripada rumah tangga miskin. Fenomena ini memberikan gambaran bahwa pada masyarakat perdesaan sektor pertanian perannya makin kecil dibandingkan sektor non pertanian, atau telah terjadi transformasi sosial dimana nilai pertanian terhadap masyarakat telah menurun (Fridayanti \& Dharmawan, 2013). Pilihan usaha ternak domba sebagai aktivitas nafkah untuk pengentasan kemiskinan dapat dipertimbangkan untuk terus didorong, melalui penyediaan aset produktif yang lebih besar dapat diakses buruh tani.

\section{Analisis Penduga Status Kemiskinan Buruh Tani Ternak Domba}

Pengolahan data dengan perangkat SPSS 22 dari responden sebanyak 87 orang, terdiri dari 65 orang responden buruh tani ternak domba dengan status miskin dan 22 orang berstatus tidak miskin menghasilkan hasil uji sebagai berikut.

Hasil pengujian kecocokan model (goodness of fit test) menunjukkan bahwa nilai $p$ value sebesar 0,537>0,05 (Tabel Hosmer \& Lemeshow Test) artinya model dapat digunakan untuk menjelaskan hubungan antara status kemiskinan dengan variabel bebasnya. Model dapat mengklasifikasikan objek secara benar sebesar 86,2 persen. Hasil pengolahan data (Omnibus Tests of Model Coefficients Table) menunjukkan $p$-value sebesar $0,000<5 \%$, artinya minimal ada satu variabel bebas secara statistik berpengaruh signifikan terhadap peluang status kemiskinan buruh tani.

Hasil uji parsial menunjukkan nilai statistik Wald lebih besar dari nilai kritis $X^{2}$ pada derajat bebas 1 pada tingkat signifikansi sebesar 5\%, atau nila $p$-value $<5 \%$ (Tabel 2). Hasil identifikasi menunjukan bahwa pengalaman beternak dan usia peternak tidak berpengaruh terhadap status kemiskinan rumah tangga buruh tani ternak domba. Sedangkan variabel usaha non pertanian, keanggotaan dalam kelembagaan kelompok peternak, jumlah kepemilikan domba serta jumlah anggota rumah tangga secara signifikan mempengaruhi status kemiskinan rumah tangga buruh tani ternak domba. 
Tabel 1. Profil buruh tani ternak domba di Desa Walangsari

\begin{tabular}{llrr}
\hline \multirow{2}{*}{ No } & \multicolumn{1}{c}{ Kriteria } & \multicolumn{2}{c}{ Buruh Tani } \\
\cline { 3 - 4 } & & Tidak Miskin & Miskin \\
\hline 1 & Jumlah anggota rumah tangga (orang/rumah tangga) & 3,59 & 4,72 \\
2 & Jumlah kepemilikan domba (ekor/rumah tangga) & 13,14 & 11,03 \\
3 & Pendapatan total rumah tangga (Rp/tahun) & $28.182 .609,85$ & $14.156 .619,23$ \\
4 & Kontribusi usaha ternak domba terhadap pendapatan total ( \% ) & 46,86 & 53,36 \\
5 & Kontribusi usahatani (on farm dan offfarm) terhadap pendapatan total (\%) & 31,35 & 37,79 \\
6 & Kontribusi usaha lain (non farm) terhadap pendapatan total ( \% ) & 21,79 & 8,85 \\
\hline
\end{tabular}

Tabel 2. Pengaruh berbagai variabel terhadap kemiskinan buruh tani

\begin{tabular}{llrrrr}
\hline \multicolumn{1}{c}{ Variabel } & \multicolumn{1}{c}{ B } & \multicolumn{1}{c}{ S.E } & Wald & p-value & \multicolumn{2}{c}{$\begin{array}{c}\text { Odds ratio } \\
(\operatorname{exp~B})\end{array}$} \\
\hline Konstanta & $-0,364$ & 2,096 & 0,030 & 0,862 & $-0,695$ \\
Pengalaman memelihara domba $\left(\mathrm{X}_{1}\right)$ & 0,065 & 0,054 & 1,412 & 0,235 & 1,067 \\
Usaha non pertanian $\left(\mathrm{X}_{2}\right)$ & 2,420 & 0,742 & 10,639 & $0,001^{* *}$ & 11,247 \\
Anggota Koperasi $\left(\mathrm{X}_{3}\right)$ & 1,552 & 0,785 & 3,911 & $0,048^{*}$ & 4,721 \\
Jumlah Kepemilikan Domba $\left(\mathrm{X}_{4}\right)$ & 0,144 & 0,066 & 4,751 & $0,029^{*}$ & 1,154 \\
Usia Kepala Rumah Tangga $\left(\mathrm{X}_{5}\right)$ & $-0,088$ & 0,031 & 0,072 & 0,788 & 0,992 \\
Jumlah Anggota Rumah Tangga $\left(\mathrm{X}_{6}\right)$ & $-1,052$ & 0,395 & 7,093 & $0,008^{* *}$ & 0,349 \\
\hline
\end{tabular}

Keterangan : ** Signifikan pada $\mathrm{P}<0,01$; * signifikan pada $\mathrm{P}<0,05$

Variabel usia kepala rumah tangga serta pengalaman beternak domba tidak berpengaruh terhadap kecenderungan miskin atau tidak miskin. Variabel yang berpengaruh terhadap status kemiskinan adalah sumber nafkah non pertanian. Rumah tangga buruh tani yang mempunyai aktivitas nafkah non pertanian (off dan non farm) mempunyai peluang besar berada pada kondisi tidak miskin. Kecenderungan buruh tani menjadi miskin akan lebih besar bila anggota keluarganya banyak serta tidak mempunyai sumber nafkah non pertanian. Keadaan ini memberi gambaran pentingnya sektor off farm dan non farm dalam menunjang kehidupan masyarakat perdesaan, sektor pertanian on farm makin tidak dapat diandalkan sebagai sumber nafkah utama. Kecederungan masyarakat pertanian tidak lagi mengandalkan pertanian (on farm) sebagai sumber nafkah utama, dilaporkan oleh Oktalina et al. (2016); dan Wijayanti et al. (2016).

Variabel penting yang berpengaruh terhadap status kemiskinan adalah jumlah kepemilikan domba serta keterlibatannya dalam kelembagaan. Makin banyak jumlah domba yang dimiliki, serta terlibat dalam kelembagaan peternak, maka rumah tangga buruh tani tersebut cenderung menjadi tidak miskin.Temuan ini menegaskan adanya peluang untuk terus mengembangkan usaha ternak domba sebagai aktivitas nafkah sebagai jalur keluar dari kondisi miskin pada buruh tani. Pendapat yang sama dikemukakan Randolph etal. (2007), karena ternak mampu memperkuat aset produktif. Kelembagaan masyarakat diperlukan untuk membantu menjalankan program pengentasan kemiskinan dalam rangka pengelolaan berbagai aset penghidupan, supaya dapat bekerja efektif dan efisien.

\section{Usaha Ternak Domba pada Rumah Tangga Buruh Tani}

Hasil penelitian menunjukan bahwa jumlah kepemilikan domba berpengaruh terhadap status kemiskinan rumah tangga buruh tani. Makin banyak jumlah domba yang dipelihara, peluang buruh tani untuk keluar dari kondisi miskin akan semakin besar. Usaha ternak domba sangat bermakna berkontribusi terhadap pendapatan rumah tangga buruh tani, maka domba menjadi sangat potensial digunakan untuk pengentasan kemiskinan (Baidoo et al., 2016). Pada dasarnya kemiskinan masyarakat perdesaan disebabkan oleh terbatasnya kepemilikan modal penghidupan, oleh karena itu upaya memperbesar pemilikan dan penguasaan aset akan berdampak pada pengentasan kemiskinan. Menurut Livestock Production Programme DFID (2004), pemilihan ternak sebagai sebagai aktivitas nafkah telah memenuhi syarat, karena ternak dapat berfungsi sebagai aset dan usaha ternaknya sebagai aktivitas yang didalamnya terkandung atribut : produktivitas (productivity), bernilai guna (utility), memberikan pengamanan (security), menekan biaya (holding cost), hidup-bertumbuh dan berkembang (life), berdaya ubah (convertibility), berkomplementer (complementary) dan kepemilikannya mudah dikontrol (ownership/control).

Fungsi penduga untuk mengetahui pengaruh jumlah pemilikan (X) terhadap pendapatan dari usaha ternak domba (Y) diperoleh sebagai berikut : 
$\mathrm{Y}=2253291,22+487350,23 \mathrm{X}\left(\mathrm{R}^{2}=0,54372179\right) \ldots \ldots \ldots$ (1)

Model tersebut menunjukkan bahwa jumlah pemilikan domba berpengaruh sangat nyata terhadap besarnya pendapatan rumah tangga pada buruh tani ternak domba. Makin banyak jumlah peliharaan domba, nilai pendapatan rumah tangga akan makin besar.

Pada rata-rata jumlah anggota rumah tangga buruh tani sebanyak 4,45 orang, batas kemiskinan berada pada besaran pengeluaran rumah tangga sebesar $\mathrm{Rp} 1.675 .576,55$ per bulan atau $\mathrm{Rp}$ 20.106.918,62 per tahun. Menggunakan fungsi penduga (1) ditentukan jumlah kepemilikan domba yang mampu memenuhi batas minimal status miskin adalah 36,63 ekor atau 3,51 satuan ternak, dengan asumsi rumah tangga tersebut menjadikan usaha ternak domba sebagai usaha pokok. Bila rumah tangga tetap mempertahankan pekerjaannya sebagai buruh tani, maka untuk keluar dari kemiskinan harus memelihara domba minimal sebanyak 21,37 ekor atau 2,65 satuan ternak. Pilihan aktivitas nafkah usaha ternak domba sebagai sarana untuk mengentaskan kemiskinan merupakan pilihan rasional, karena domba dapat berfungsi sebagai aset produktif dan tabungan multi fungsi, menggunakan input lokal yang besar (low external input) dan murah (Johnson et al., 1986), serta mempunyai risiko produksi dan risiko pasar yang dapat dikendalikan oleh rumah tangga buruh tani miskin (Randolph et al., 2007).

\section{KESIMPULAN}

Jumlah kepemilikan domba dan keterlibatan buruh tani ternak domba dalam kelembagaan berpengaruh terhadap kemiskinan mereka. Oleh karena itu usaha ternak domba dapat digunakan sebagai aktivitas nafkah untuk mengentaskan kemiskinan buruh tani di perdesaan. Jumlah domba minimal yang harus dipelihara untuk mengeluarkan rumah tangga buruh tani dari kemiskinan sebanyak 36,63 ekor atau 3,51 satuan ternak. Bila rumah tangga masih tetap mempertahankan pekerjaan utamanya sebagai buruh tani, dan usaha ternak domba merupakan sumber pendapatan tambahan (second income), maka untuk keluar dari kemiskinan harus memelihara domba minimal sebanyak 21,37 ekor atau 2,65 satuan ternak.

Pengentasan kemiskinan buruh tani peternak domba di perdesaan dapat dilakukan melalui program pembibitan domba yang terkontrol untuk meningkatkan jumlah kepemilikan domba. Program pengentasan kemiskinan harus melibatkan kelembagaan lokal yang kuat sebagai upaya konsolidasi dan penguatan aset yang dapat diakses buruh tani miskin.Jumlah kepemilikan domba yang banyak, harus didukung oleh ketersediaan kebun rumput, serta introduksi teknologi pengawetan pakan, untuk menjaga kesinambungan ketersediaan rumput sepanjang tahun.

\section{DAFTAR PUSTAKA}

Asra, A., A. Utomo., M. Asikin, \& N.H. Pusponegoro. 2017. Analisis Multivariabel. Penerbit In Media. Bogor.

[BPS] Badan Pusat Statistik. 2017. Statistik Kesejahteraan Rakyat Kabupaten Sukabumi 2017. Badan Pusat Statistik Kabupaten Sukabumi. Sukabumi.

[BPS] Badan Pusat Statistik Jawa Barat. 2019. Tingkat Kemiskinan dan Ketimpangan di Jawa Barat Maret 2019. Berita Resmi Statistik. No.38/07/32/Th. XXI, 15 Juli 2019. [18 Januari 2020]

Johnson, W.L., J.E van Eys, \& H.A. Fitzhugh, 1986. Sheep and goats in tropical and subtropical agricultural systems. Journal of Animal Science 63:1587-1599.

Kecamatan Kalapanunggal dalam Angka, 2018. Badan Pusat Statistik Kabupaten Sukabumi. No. Publikasi: 3202.18.1. Katalog BPS : 1102001.3202.

Baidoo, S.T., H. Yusif, \& U. Anwar, 2016. The Effect of smallholder livestock production on income of farm household in Northern Ghana. Journal of Science and Technology 36 (3):8-19.

Bettencourt, E.M.V., M. Tilman., V. Narciso., M.L.S. Carvalho, \& P.D.S. Henriques, 2015. The Livestock Roles in The Wellbeing of Rural Communities of Timor Leste. RESR, Piracicaba-SP vol 53, supl. 1, SO63 - SO80 - Impressa em marco de 2015.

Biradar, N., M. Desai., L. Manjunath, \& M.T. Doddamani. 2013. Assesing contribution of livestock to the livelihood of farmers of Western Maharashtra. J Hum Ecol 41(2): 107-112.

Chiang, A.C. 1974. Fundamental Methods of Mathematical Economics. McGraw-Hill Kogakusha, Ltd. Tokyo. Singapore. Sydney.

Ciamarra, U.P. 2005. Livestock Policies for Poverty Alleviation: Theory and Practical 
Evidence from Africa, Asia and Latin America. PPLPI working paper no 27.

Fridayanti, N. \& A.H. Dharmawan, 2013. Analisis struktur dan strategi nafkah rumah tangga petani sekitar kawasan hutan konservasi di Desa Cipeuteuy, Kabupaten Sukabumi. Sodality: Jurnal Sosiologi Pedesaan 1(1): $29-42$.

Kuswaryan, S., A. Fitriani, \& S. Nurjanah. 2016. Peran usaha ternak domba sebagai pengaman finansial keluarga di pedesaan. Seminar Nasional "Inovasi Ipteks Perguruan Tinggi untuk Meningkatkan Kesejahteraan Masyarakat". UNMAS Bali, 29-30 Agustus 2016.

Kuswaryan, S., \& C. Firmansyah, 2017. Jumlah peliharaan dan kebutuhan tenaga kerja pada usaha ternak domba sebagai sumber pendapatan utama keluarga. Seminar Nasional Pengembangan Peternakan Berkelanjutan ke-9. Desember 2017. UNPAD Bandung.

Kumar, S., R.K. Vaid, \& R.L. Sagar, 2006. Contribution of goat to livelihood security of small ruminant farmers in semiarid region. Indian Journal of Small Ruminant 12(1):6166.

Livestock Production Programme DFID. 2004. A Guide to Indicators \& Methods for Assessing the Contribution of Livestock Keeping to Livelihoods of The Poor. Departemen Agricultural Sciences. Imperial College. London.

Maltsoglou, I. \& G. Rapsomanikis, 2005. The Contribution of Livestock to Household Income in Vietnam: A Household Typology Based Analysis. PPLPI Working Paper No. 21. http://www.fao.org/3/bp213e/bp213e.pdf [20 Agustus 2020].
Oktalina, S.N., S.A.W. Awang., S. Hartono, \& P. Suryanto. 2016. Pemetaan aset penghidupan petani dalam pengelolaan hutan rakyat di Kabupaten Gunung Kidul. J Manusia dan Lingkungan 23(1):58-65.

Randolph, T.F., E. Schelling, D. Grace, C.F. Nicholson, J.L. Leroy, D.C. Cole, M.W. Demmet, A. Omore, J. Zinsstag, \& M. Ruel, 2007. Role of livestock in human nutrition and health for poverty reduction in developing countries. Journal of Animal Science 85:2788-2800.

Swanepoel, F., A. Stroebel, \& S. S. Moyol, 2010. The Role of Livestock In Developing Commu-Nities: Enhancing Multifunctionality. The Technical Centre for Agricultural And Rural Cooperation (CTA). Bloemfontein. South Africa.

Tembo, G., A. Tembo, F. Goma, E. Kapekele, \& J. Sambo. 2014. Livelihood activities and the role of livestock in smallholder farming communities of Southern Zambia; Open Journal of Social Sciences 2:299-307.

Udo, H.M.J. \& I.G.S. Budisatria, 2011. Fat-tailed sheep in Indonesia: an essential resources for smallholders. Trop Anim Health Prod 43(7):1411-1418.

Ugwu, D.S, 2007. The role of small ruminants in the household economy of the Southeast Zone of Nigeria. Research Journal of Applied Science 2(6):726-732.

Wijayanti, R., M. Baiquni., \& R. Harini, 2016. Strategi penghidupan berkelanjutan masyarakat berbasis aset di sub DAS Pusur, DAS Bengawan Solo. Jurnal Wilayah dan Lingkungan 4(2):133-152. 